\title{
PENGARUH KONSENTRASI ASAP CAIR TEMPURUNG KENARI DAN LAMA PENYIMPANAN TERHADAP KUALITAS KIMIA DAN FISIK DAGING
}

\section{THE EFFECT OF CANARY SHELL LIQUID SMOKE CONCENTRATION AND STORAGE TIME ON CHEMICAL AND PHYSICAL QUALITY OF BEEF}

\author{
Rizki Arizona*, Edi Suryanto, dan Yuny Erwanto \\ Fakultas Peternakan, Universitas Gadjah Mada, Jl. Fauna No. 3, Bulaksumur, Yogyakarta, 55281
}

\section{INTISARI}

Penelitian ini bertujuan untuk mengetahui pengaruh asap cair tempurung kenari terhadap kualitas kimia, fisik serta sensoris daging selama penyimpanan pada suhu kamar. Daging direndam larutan asap cair $(0,4,8$, dan $12 \%) \mathrm{v} / \mathrm{v}$ selama 15 menit dan disimpan pada suhu kamar selama 0, 2, dan 4 hari. Variabel yang diukur meliputi kadar air, kadar fenol, kadar asam, pH, daya ikat air (DIA), susut masak (SM), dan sensoris daging. Rancangan penelitian yang digunakan adalah Completely Randomized Design (CRD) pola faktorial 4x3. Data kualitas kimia dan fisik daging dianalisis dengan analisis variansi. Data kualitas sensoris dianalisis dengan uji Hedonic Kruskal-Wallis. Hasil penelitian menunjukkan bahwa konsentrasi asap cair berpengaruh secara nyata $(\mathrm{p}<0,05)$ terhadap DIA. Level asap cair yang semakin meningkat menyebabkan DIA daging semakin meningkat. Lama penyimpanan daging hingga hari keempat menunjukkan perbedaan yang nyata $(\mathrm{p}<0,05)$ terhadap $\mathrm{pH}$, susut masak, sedangkan DIA daging menurun. Uji sensoris menunjukkan bahwa aroma dan perlendiran daging terdapat perbedaan yang nyata $(\mathrm{p}<0,05)$ diantara perlakuan. Tidak ada interaksi antara konsentrasi asap cair dan lama penyimpanan. Kesimpulan dari penelitian ini adalah penambahan asap cair hingga konsentrasi 12\% meningkatkan kadar fenol dan asam, sedangkan kualitas fisik daging mengalami penurunan. Daging asap yang disimpan hingga 4 hari menunjukkan penurunan mutu seperti pH, DIA, SM, serta sensoris daging.

(Kata kunci: Tempurung kenari, Asap cair, Lama penyimpanan, Kualitas daging)

\section{ABSTRACT}

The objective of the experiment study was to determine the effect of canary shell liquid smoke on the chemical, physical and sensory qualities of beef stored at room temperature. Beef samples were dipped in liquid smoke solution with the concentration of $0,4,8$, and $12 \%(v / v)$ during 15 minutes and then stored for 0,2, and 4 days at room temperature. Each treatment was carried out three times and the variables measured were water, phenol and acid content, $p H$, water-holding capacity, cooking loss and sensory properties of samples. Data on chemical and physical qualities were analyzed using analysis of variance (Completely Randomized Design/CRD) with factorial 4x3. The sensory properties were analyzed by a non parametric h-test. The results showed that liquid smoke concentration up to $12 \%$ significantly $(p<0.05)$ increased water holding capacity and cooking loss of samples. Storage time up to four days significantly $(p<0.05)$ increased its $\mathrm{pH}$ value, cooking loss, whereas water-holding capacity was decreased. The meat sensory test showed that flavor and slimming rate were affected significantly $(p<0.05)$ by liquid smoke. There was no interaction between liquid smoke concentration and storage time. In conclusion, the addition of liquid smoke up to $12 \%$ increased phenol and acid content, while the physical quality of meat has decreased. Quality of beef stored up to 4 days showed a decreased of quality such as $\mathrm{pH}$, water-holding capacity, cooking loss, and sensory meat.

(Keywords: Canary shell, Liquid smoke, Storage time, Quality of beef)

\section{Pendahuluan}

Daging merupakan bahan pangan yang mudah mengalami kerusakan bila tanpa usaha penanganan dan pengawetan. Proses pengasapan adalah salah satu metode tradisional dengan menggunakan pembakaran secara langsung namun

\footnotetext{
* Korespondensi (corresponding author):

Telp.+62 8524242 7051, E-mail: zonarizki@yahoo.com
}

kelemahannya adalah terdepositnya tar pada bahan makanan sehingga membahayakan kesehatan. Kelemahan tersebut dapat diatasi dengan penggunaan asap cair. Tempurung kenari mempunyai tekstur yang sangat padat dan keras sehingga dapat digunakan sebagai bahan baku pembuatan asap cair. Asap cair tersebut dapat diaplikasikan pada pangan 
sebagai bahan pengawet alami. Penelitian tentang produksi asap cair, senyawa fungsional dan pengujian kualitas senyawa fungsional telah banyak dilakukan dari berbagai jenis kayu dan limbah tanaman perkebunan, khususnya untuk tempurung kelapa telah diteliti secara mendalam, namun pengujian asap cair dengan bahan baku tempurung kenari belum dilakukan.

Asap cair mengandung berbagai senyawa yang dapat dikelompokkan ke dalam fenol, asam dan karbonil (Pszczola, 1995). Senyawa kimia utama yang terdapat di dalam asap antara lain asam formiat, asetat, butirat, kaprilat, vanilat dan asam siringat, dimetoksifenol, metal glioksal furfural, methanol, etanol, oktanol, asetaldehid, diasetil, aseton dan 3,4 benzopiren (Lawrie, 2003). Senyawa kimia tersebut dapat berperan sebagai bakteriostatik, bakteriosidal dan dapat menghambat oksidasi lemak karena senyawa kimia yang terdapat di dalam asap akan menempel pada daging yang akan memberikan efek preservatif, sehingga dapat menghambat pertumbuhan mikroba yang pada akhirnya lama penyimpanan dapat diperpanjang.

Asap cair diketahui mengandung berbagai komponen organik yang berperanan, selain membentuk cita-rasa khas, asap juga dapat memberikan warna coklat keemasan pada produk daging (Daun, 1979). Hasil olahan daging mudah mengalami kerusakan mutu pada penyimpanan suhu dan kelembaban kamar. Suradi (2005) melaporkan bahwa daging sapi mempunyai masa simpan 17 jam. Fitryani (2009) melaporkan sosis sapi asap selama penyimpanan 6 hari suhu $\pm 5^{\circ} \mathrm{C}$ akan meningkatkan kadar air. Penelitian mengenai perubahan mutu daging sapi yang diawetkan asap cair pada penyimpanan suhu kamar belum pernah dilakukan. Berdasarkan uraian tersebut, perlu dilakukan penelitian pengaruh asap cair tempurung kenari terhadap kualitas kimia, fisik dan sensoris daging yang disimpan pada suhu kamar, sehingga aman untuk dikonsumsi dengan pengolahan lebih lanjut.

\section{Materi dan Metode}

Bahan yang digunakan dalam penelitian ini adalah asap cair tempurung kenari, daging sapi, plastik polietilen, aquadest, larutan $10 \% \mathrm{NAOH}$, kertas saring, phenolphthalein $1 \%$, larutan natrium nitrit, larutan 20\% Na-karbonat, $\mathrm{H}_{3} \mathrm{PO}_{3} \quad 10 \%$. Peralatan yang digunakan yaitu oven, timbangan analitik, pH meter, erlenmeyer, tabung reaksi, mikropipet, dan vochdoos.

\section{Persiapan sampel}

Daging sapi bagian longissimus dorsi diiris tipis mengikuti arah jaringan otot sekitar $4 \times 4 \times 2 \mathrm{~cm}$.
Daging direndam dalam asap cair selama 15 menit. Level asap cair yang digunakan yaitu $0,4,8$, dan $12 \%$. Daging yang telah direndam dalam asap cair selanjutnya dikemas dalam plastik polyethylene dan disimpan pada suhu kamar. Pengamatan dilakukan pada 0,2 , dan 4 hari dan diulang sebanyak 3 kali.

\section{Variabel yang diamati}

Kadar air. Kadar air daging dianalisis berdasarkan metode AOAC (1995). Sampel seberat $\pm 1,0 \mathrm{~g}$ (y) ditimbang, kemudian dimasukkan dalam oven suhu $105^{\circ} \mathrm{C}$ selama 12 jam, didinginkan dalam desikator selama 1 jam dan ditimbang (penimbangan diulang tiga kali setiap jam sampai diperoleh berat sampel yang konstan (z). Kadar air dihitung dengan menggunakan rumus:

$$
\text { Kadar air }=\frac{y-z}{y} \times 100 \%
$$

Kadar fenol. Metode yang digunakan berdasarkan pada Senter et al. (1989), modifikasi dengan metode Plumer (1971) cit. Fiddian (2002). Sampel asap cair sebanyak $1 \mathrm{ml}$ ditimbang, kemudian diencerkan hingga mencapai volume 100 $\mathrm{ml}$, total pengenceran $=100 \mathrm{kali}(\mathrm{fp}=100 \mathrm{kali})$ sedangkan untuk sampel daging sapi yang sudah dihancurkan ditimbang $1 \mathrm{~g}$, kemudian diencerkan dalam labu takar $5 \mathrm{ml}$, total pengenceran $5 \mathrm{kali}(\mathrm{fp}=$ 5 kali). Hasil pengenceran kemudian diambil $1 \mathrm{ml}$ dan ditambah $5 \mathrm{ml}$ larutan $\mathrm{Na}_{2} \mathrm{CO}_{3}$ alkali $2 \%$, divortex dan dibiarkan selama 10 menit. Selanjutnya ditambahkan larutan folin ciopcalteu sebanyak 0,5 $\mathrm{ml}$ dengan perbandingan aquadest $1: 1$, divortex dan dibiarkan selama 30 menit, kemudian ditera pada panjang gelombang $750 \mathrm{~nm}$. Larutan blanko dibuat sama dengan penetapan sampel, akan tetapi sampel diganti dengan aquadest. Konsentrasi fenolat larutan sampel dihitung berdasarkan kurva standar yang diperoleh dari larutan fenol murni.

Kadar asam. Analisis kadar asam daging menggunakan metode AOAC (1995). Sampel daging ditimbang satu g, sedangkan untuk sampel asap cair sebanyak satu ml. Sampel kemudian dihaluskan dan ditambahkan $25 \mathrm{ml}$ aquadest, dan dimasukkan dalam erlenmeyer, selanjutnya ditambahkan 2-3 tetes phenolphthalein 1\% dititrasi dengan $\mathrm{NaOH} 0,1 \mathrm{~N}$ hingga berubah menjadi merah muda (warna tetap). Skala penurunan $\mathrm{NaOH}$ yang dibaca digunakan dalam menghitung keasaman dengan rumus :

$$
\% \text { keasaman }=\frac{m l N a O H x N N a O H x 60}{m g \text { sampel }} \times 100 \%
$$

Nilai pH. Pengujian $\mathrm{pH}$ daging dilakukan dengan menggunakan metode Bouton et al. (1971) cit. Soeparno (2005). Sampel daging seberat $10 \mathrm{~g}$ dihaluskan kemudian dicampur dengan $10 \mathrm{ml}$ 
aquadest hingga homogen dan kemudian diukur dengan $\mathrm{pH}$ meter. Elektroda gelas pada $\mathrm{pH}$ meter dicuci dengan aquadest dan dikeringkan dengan tissu. Pengukuran dilakukan tiga kali dan hasilnya direrata sebagai nilai $\mathrm{pH}$ daging.

Daya ikat air daging (water-holding capacity/WHC). Pengujian daya ikat air daging berdasarkan metode Hamm (1972) cit. Soeparno (2005). Daya ikat air daging dapat dihitung dengan rumus sebagai berikut:

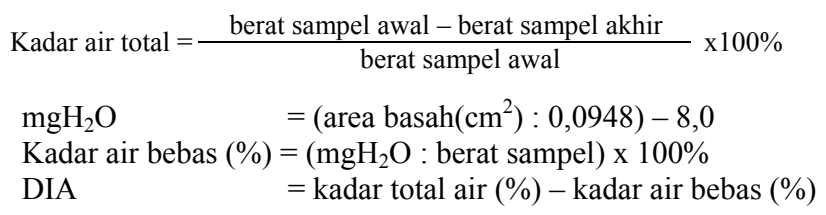

Susut masak daging (cooking loss/CL). Uji susut masak daging menggunakan metode Bouton et al. (1971) cit. Soeparno (2005). Penyusutan berat sebelum dan sesudah dimasak dibagi berat daging sebelum masak dikali $100 \%$ adalah besarnya susut masak.

Uji sensoris. Kualitas sensoris daging diuji menggunakan metode skor (Guritno, 1991) yang meliputi warna, bau, dan kenampakan. Panelis sejumlah 15 orang terlibat dalam pengujian ini.

\section{Analisa data}

Data yang diperoleh dianalisis dengan menggunakan analisis variansi (Completely Randomized Design (CRD) pola faktorial $4 \times 3$ ). Faktor pertama konsentrasi asap cair $(0,4,8$, dan $12 \%)$ dan lama penyimpanan $(0,2$, dan 4 hari). Data diuji lanjut dengan Duncan's New Multiple Range Test (DMRT) (Gazpersz, 1994). Data hasil uji sensoris dianalisis dengan analisis non-parametrik dengan uji Hedonik Kruskal-Wallis (Steel dan Torrie, 1993).

\section{Hasil dan Pembahasan}

\section{Kualitas kimia daging}

Kadar air. Hasil analisis statistik menunjukkan bahwa konsentrasi asap cair dan lama penyimpanan berpengaruh tidak nyata terhadap kadar air daging, tidak ada interaksi antara konsentrasi asap cair dan lama penyimpanan terhadap kadar air daging. Kadar air pada masing-masing perlakuan jika dibandingkan dengan kontrol $(0 \%)$ menghasilkan kadar air yang relatif sama. Konsentrasi asap cair hingga $12 \%$ tidak mampu mempengaruhi kadar air daging. Rerata kadar air daging pada berbagai konsentrasi asap cair dan lama penyimpanan disajikan pada Tabel 2. Gronulalan et al. (2003) menyatakan bahwa kadar air lidah sapi yang direndam asap cair tidak menunjukkan perbedaan yang nyata selama penyimpanan 30 hari pada suhu $4 \pm 1^{\circ} \mathrm{C}$. Asap cair tempurung kelapa hingga konsentrasi $6 \%$ berpengaruh tidak nyata terhadap kadar air sosis sapi (Fitryani, 2009).

Kadar fenol. Hasil analisis statistik menunjukkan bahwa konsentrasi asap cair berpengaruh tidak nyata terhadap kadar fenol daging, namun demikian masih tetap ada kecenderungan perubahan kadar fenol daging. Berdasarkan data Tabel 2, semakin tinggi konsentrasi asap cair semakin tinggi

Tabel 1. Kriteria skor yang digunakan pada uji sensoris (criteria used in the scores of sensory test)

\begin{tabular}{clll}
\hline \hline $\begin{array}{c}\text { Skor } \\
\text { (score })\end{array}$ & \multicolumn{1}{c}{ Warna (color) } & \multicolumn{1}{c}{ Aroma (flavor) } & \multicolumn{1}{c}{ Kenampakan (appearances) } \\
\hline 5 & Merah terang (light red) & Sangat berbau asap (hard smoked) & Tidak berlendir (not slimy) \\
4 & Merah agak terang (lightly red) & Berbau asap (smoked) & Agak berlendir (rather slimy) \\
3 & Merah (red) & Tidak berbau asap (not smoked) & Berlendir (slimy) \\
2 & Merah agak gelap (darkly red) $)$ & Agak busuk (rather spiled) & Sangat berlendir (very slimy) \\
1 & Merah gelap (dark red) & Busuk (spiled) & Rusak (damaged) \\
\hline
\end{tabular}

Tabel 2. Rerata kualitas kimia daging pada berbagai konsentrasi asap cair dan lama penyimpanan (mean of chemical quality of liquid smoked beef at various concentration and storage time)

\begin{tabular}{|c|c|c|c|c|c|c|c|}
\hline \multirow{2}{*}{$\begin{array}{l}\text { Kualitas kimia daging } \\
\text { (chemical quality of beef) }\end{array}$} & \multicolumn{4}{|c|}{$\begin{array}{c}\text { Konsentrasi asap cair }(\%) \\
\text { (liquid smoke concentration (\%)) }\end{array}$} & \multicolumn{3}{|c|}{$\begin{array}{c}\text { Lama penyimpanan (hari) } \\
\text { (storage time (days)) }\end{array}$} \\
\hline & 0 & 4 & 8 & 12 & 0 & 2 & 4 \\
\hline Kadar air (water content) $)^{\mathrm{ns}}$ & 76,04 & 75,74 & 74,67 & 74,88 & 75,44 & 74,62 & 75,92 \\
\hline Kadar fenol (phenol content $)^{\mathrm{ns}}$ & 0,16 & 0,16 & 0,17 & 0,21 & 0,19 & 0,18 & 0,14 \\
\hline Kadar asam (acid content) & 0,34 & 0,35 & 0,35 & 0,39 & $0,45^{\mathrm{a}}$ & $0,37^{\mathrm{b}}$ & $0,26^{\mathrm{c}}$ \\
\hline
\end{tabular}

${ }^{a, b, c}$ Superskrip yang berbeda pada baris yang sama menunjukkan perbedaan yang nyata $(\mathrm{p}<0,05)($ different superscripts at the same row indicate significant differences ( $p \square 0.05)$ ). 
kadar fenol daging. Kadar fenol asap cair tempurung kenari yang digunakan 1,26\%. Fitryani (2009) melaporkan bahwa kadar fenol asap cair dari tempurung kelapa yaitu 2996,48 ppm atau $2,99 \%$. Perendaman sosis sapi dalam asap cair hingga level $6 \%$ berpengaruh nyata terhadap kadar fenol sosis. Girard (1992); Yu dan Sun (2006) menyatakan bahwa konsentrasi dan komposisi fenol dalam asap cair bervariasi. Kandungan fenol bervariasi antara $1,10 \%$ sampai $5,13 \%$ tergantung pada macam dan bentuk kayu.

Hasil analisis statistik menunjukkan bahwa lama penyimpanan berpengaruh tidak nyata terhadap kadar fenol daging, namun demikian masih tetap ada kecenderungan perubahan kadar fenol daging; yakni pada penyimpanan 0,2 , dan 4 hari masing-masing mempunyai kadar fenol yang menurun. Tidak ada interaksi antara konsentrasi asap cair dan lama penyimpanan terhadap kadar fenol daging.

Kadar asam. Keasaman (dihitung sebagai \% asam asetat) asap cair yang terserap ke produk. Hasil analisis statistik menunjukkan bahwa konsentrasi asap cair berpengaruh tidak nyata terhadap kadar asam daging, namun demikian masih tetap ada kecenderungan perubahan kadar asam daging. Kadar asam asap cair yang digunakan dalam penelitian ini sebesar 4,33\%. Tranggono et al. (1997) menyatakan bahwa keasaman asap cair dari berbagai kayu bervariasi antara 4,27-11,39\%. Perbedaan kadar asam pada asap cair tersebut diduga disebabkan karena perbedaan komposisi kimia terutama selulosa. Girard (1992) menyatakan bahwa pirolisis selulosa berlangsung dalam dua tahap. Tahap pertama adalah reaksi hidrolisis menghasilkan glukosa, tahap kedua merupakan reaksi yang menghasilkan asam asetat, air, furan dan fenol.

Kadar asam daging pada konsentrasi asap cair 4, 8, dan 12\% lebih tinggi dibandingkan konsentrasi 0\% (kontrol). Soeparno (2005) menyatakan bahwa daging segar mengandung asam laktat, asam sitrat, asam fumarat, asam suksinat dan asam asetoasetat.
Hasil analisis statistik menunjukkan bahwa lama penyimpanan berpengaruh nyata $(p<0,05)$ terhadap kadar asam daging. Hasil penelitian menunjukkan bahwa semakin lama penyimpanan kadar asam semakin menurun, hal ini disebabkan karena selama penyimpanan adanya aktivitas mikroba dalam menguraikan protein sehingga nilai basa-basa volatilnya meningkat dan asam yang terbentuk sedikit. Suradi (2005) menyatakan bahwa aktivitas mikroba selama penyimpanan mengakibatkan terjadinya dekomposisi protein senyawa yang lebih sederhana. Diantara senyawa-senyawa tersebut hanya merkaptan dan $\mathrm{H}_{2} \mathrm{~S}$ yang bersifat asam lemah, selebihnya bersifat basa dan basa kuat, sehingga proses ini akan diikuti dengan penurunan asam dan peningkatan $\mathrm{pH}$. Hasil penelitian Chamidah (2005) menunjukkan bahwa sosis lele yang disimpan pada suhu kamar selama 4 hari total asamnya menurun. Hasil analisis statistik menunjukkan bahwa tidak ada interaksi antara konsentrasi asap cair dan lama penyimpanan terhadap kadar asam daging.

\section{Kualitas fisik daging}

Rerata kualitas fisik daging pada berbagai konsentrasi asap cair dan tempurung kenari disajikan pada Tabel 3.

Nilai pH. Konsentrasi asap cair berpengaruh tidak nyata terhadap $\mathrm{pH}$ daging, namun demikian $\mathrm{pH}$ daging pada berbagai konsentrasi asap cair cenderung menurun karena komponen asap yang melekat pada daging mempunyai sifat asam diantaranya asam karboksilat yang meliputi asam formiat, asetat dan butirat. Rerata $\mathrm{pH}$ daging pada berbagai konsentrasi asap cair dan lama penyimpanan disajikan pada Tabel 3. Hasil penelitian menunjukkan bahwa lama penyimpanan berpengaruh nyata $(\mathrm{p}<0,05)$ terhadap $\mathrm{pH}$ daging. Berdasarkan data dalam Tabel 3 menunjukkan bahwa semakin lama penyimpanan, semakin tinggi nilai $\mathrm{pH}$ daging. Nilai $\mathrm{pH}$ daging yang semakin tinggi disebabkan karena mikroba akan mendeaminasi asam amino dan menggunakan sisa molekulnya sebagai sumber energi sehingga jumlah $\mathrm{NH}_{3}$ dan $\mathrm{H}_{2} \mathrm{~S}$ meningkat.

Tabel 3. Rerata kualitas fisik daging pada berbagai konsentrasi asap cair dan lama penyimpanan (mean of physical quality of liquid smoked beef at various concentration and storage time)

\begin{tabular}{|c|c|c|c|c|c|c|c|}
\hline \multirow{2}{*}{$\begin{array}{l}\text { Kualitas fisik daging (physical quality } \\
\text { of beef) }\end{array}$} & \multicolumn{4}{|c|}{$\begin{array}{c}\text { Konsentrasi asap cair (\%) } \\
\text { (liquid smoke concentration (\%)) }\end{array}$} & \multicolumn{3}{|c|}{$\begin{array}{l}\text { Lama penyimpanan (hari) } \\
\text { (storage time (days)) }\end{array}$} \\
\hline & 0 & 4 & 8 & 12 & 0 & 2 & 4 \\
\hline $\mathrm{pH}(p H$ value $)$ & 6,71 & 6,52 & 6,28 & 6,13 & $5,99^{\mathrm{a}}$ & $6,16^{\mathrm{a}}$ & $7,09^{\mathrm{b}}$ \\
\hline Daya ikat air (water-holding capacity) & 25,64 & 23,24 & 21,17 & 21,05 & $32,58^{\mathrm{a}}$ & $19,96^{\mathrm{b}}$ & $14,16^{\mathrm{c}}$ \\
\hline Susut masak (cooking loss) & $37,84^{\mathrm{a}}$ & $39,68^{\mathrm{a}}$ & $39,67^{\mathrm{a}}$ & $43,96^{\mathrm{b}}$ & $33,87^{\mathrm{a}}$ & $41,11^{\mathrm{b}}$ & $45,88^{\mathrm{c}}$ \\
\hline
\end{tabular}


Dengan meningkatnya $\mathrm{NH}_{3}$ maka nilai $\mathrm{pH}$ juga meningkat. Suradi (2005) menyatakan bahwa aktivitas mikroba selama penyimpanan mengakibatkan terjadinya dekomposisi senyawa kimia daging, khususnya protein akan dipecah menjadi senyawa yang lebih sederhana dan apabila proses ini berlanjut terus akan menghasilkan senyawa seperti, indol, skatol, merkaptan, $\mathrm{NH}_{3}$, dan $\mathrm{H}_{2} \mathrm{~S}$.

Nilai rerata $\mathrm{pH}$ daging pada penyimpanan 0 hari berbeda tidak nyata dengan $\mathrm{pH}$ daging yang disimpan 2 hari, sedangkan nilai rerata $\mathrm{pH}$ daging penyimpanan 4 hari berbeda nyata $(\mathrm{p}<0,05)$ dengan $\mathrm{pH}$ daging penyimpanan 0 dan 2 hari. Tidak ada interaksi antara konsentrasi asap cair dan lama penyimpanan terhadap $\mathrm{pH}$ daging.

Daya ikat air. Hasil penelitian menunjukkan bahwa asap cair berpengaruh tidak nyata terhadap daya ikat air daging. Tidak ada interaksi antara konsentrasi asap cair dan lama penyimpanan terhadap daya ikat air daging. Konsentrasi asap cair yang digunakan untuk pengasapan tidak mempengaruhi daya ikat air daging, namun demikian berdasarkan data dalam Tabel 3, masih tetap ada kecenderungan perubahan daya ikat air daging yakni pada konsentrasi asap cair $0,4,8$, dan $12 \%$ masing-masing mempunyai nilai daya ikat air yang menurun. Hasil penelitian menunjukkan bahwa lama penyimpanan berpengaruh nyata $(p<0,05)$ terhadap daya ikat air daging. Berdasarkan data dalam Tabel 3 daya ikat air daging tertinggi pada kondisi awal 0 hari yaitu $32,58 \%$ dan terendah pada kondisi lama penyimpanan 4 hari yaitu $14,16 \%$. Hasil penelitian menunjukkan bahwa semakin lama penyimpanan, daya ikat air daging semakin menurun, hal ini disebabkan karena aktivitas mikroba selama penyimpanan mengakibatkan terjadinya kerusakan protein, sehingga kemampuan protein untuk mengikat air berkurang. Siskos et al. (2007); Nurwantoro (1997) menyatakan bahwa hidrolisis protein oleh mikroba proteolitik menyebabkan perubahan tekstur pada produk, hal ini disebabkan oleh koagulasi dan likuifikasi protein sehingga mempercepat pembusukan serta terjadinya penghancuran protein struktural seperti kolagen dan elastin.

Susut masak. Hasil analisis statistik menunjukkan bahwa konsentrasi asap cair berpengaruh nyata $(\mathrm{P}<0,05)$ terhadap susut masak daging. Berdasarkan data dalam Tabel 3, susut masak daging asap meningkat seiring dengan peningkatan level asap cair yakni masing-masing 37,84, 39,68, 39,67 dan $43,96 \%$ pada konsentrasi asap cair $0,4,8$, dan $12 \%$. Susut masak daging meningkat disebabkan karena asam-asam pada asap cair menyebabkan protein daging rusak sehingga ketersediaan grup reaktif protein pada daging untuk mengikat air ber- kurang, mengakibatkan susut masak menjadi lebih besar.

Hasil penelitian menunjukkan bahwa lama penyimpanan berpengaruh nyata $(p<0,05)$ terhadap susut masak daging. Semakin lama penyimpanan, susut masak daging semakin meningkat, disebabkan karena protein daging telah dimanfaatkan oleh mikroba, sehingga kemampuan protein untuk mengikat air semakin berkurang mengakibatkan susut masak daging menjadi lebih besar. Tidak ada interaksi antara konsentrasi asap cair dan lama penyimpanan terhadap susut masak daging. Pengaruh konsentrasi asap cair menunjukkan adanya perbedaan yang nyata terhadap susut masak daging. Rerata konsentrasi asap cair $12 \%$ berbeda nyata dengan konsentrasi asap cair 0,4 , dan $8 \%$, sedangkan antara konsentrasi 0,4 , dan $8 \%$ berbeda tidak nyata.

\section{Uji sensoris daging}

Warna. Hasil analisis statistik menunjukkan, konsentrasi asap cair berpengaruh tidak nyata terhadap warna daging. Skor warna daging tertinggi pada konsentrasi $12 \%$ yaitu 2,11 sedangkan skor terendah pada konsentrasi $0 \%$ yaitu 1,66. Rerata hasil uji sensoris terhadap daging pada berbagai konsentrasi asap cair dan lama penyimpanan disajikan pada Tabel 4. Warna daging berkisar antara merah agak gelap sampai merah gelap. Semakin tinggi konsentrasi asap cair maka warna daging menjadi merah agak gelap. Warna gelap yang terjadi pada produk asapan merupakan hasil reaksi non-enzimatik, melalui reaksi kondensasi antara karbonil dan dikarbonil dalam asap dengan asamasam amino protein dan asam amino bebas dalam produk pangan. Kandungan karbonil dan dikarbonil masing-masing asap cair sangat berbeda sehingga potensi pencoklatannya pun berbeda (Darmadji, 1999). Skor warna daging selama penyimpanan hingga 4 hari yaitu 1 sampai 3,15. Skor warna daging semakin menurun seiring dengan lama penyimpanan. Semakin lama penyimpanan warna daging semakin merah gelap, disebabkan karena pertumbuhan mikroba pada daging dapat menyebabkan perubahan warna menjadi merah gelap. Perubahan warna disebabkan oleh perubahan atau destruksi pigmen daging. Mioglobin dapat dioksidasi menjadi metmioglobin yang coklat, dan dapat bercampur dengan $\mathrm{H}_{2} \mathrm{~S}$ yang diproduksi oleh mikroba untuk membentuk sulfur mioglobin atau dipecah dan membentuk pigmen kuning atau hijau oleh hidrogen peroksida yang dibentuk oleh mikroba.

Hasil uji Kruskal-Wallis menunjukkan bahwa konsentrasi asap cair memberikan pengaruh yang tidak nyata terhadap warna daging. Asap cair dapat mempengaruhi warna produk apabila dikombinasi 
Tabel 4. Rerata hasil uji sensoris daging pada berbagai konsentrasi asap cair dan lama penyimpanan (mean of sensory test scores of liquid smoked beef at various concentration and storage time)

\begin{tabular}{cccc}
\hline \hline Variabel (variable) & Warna $(\text { color })^{\mathrm{ns}}$ & Aroma (flavor) $^{*}$ & ${\text { Perlendiran }(\text { slimming })^{*}}^{\text {Konsentrasi asap cair (\%) (liquid smoke }}$ \\
concentration (\%)) & & & \\
0 & 1,66 & 1,66 & 2,51 \\
4 & 1,91 & 2,71 & 2,86 \\
8 & 1,71 & 2,8 & 3,93 \\
12 & 2,11 & 4,15 & 4,15 \\
Lama penyimpanan (hari) (storage time & & & \\
$($ days $)$ ) & 3,15 & 4,08 & 5,00 \\
0 & 1,40 & 2,85 & 3,18 \\
2 & 1,00 & 1,56 & 1,92 \\
4 & &
\end{tabular}

dengan pemanasan. Daun (1979) dan Ruiter (1979) menyatakan bahwa warna yang ditimbulkan oleh asap diduga disebabkan oleh adanya interaksi antara karbonil yang terkandung dalam asap dengan sejumlah asam amino yang terkandung pada permukaan produk yang diasap. Mekanisme pembentukan warna tersebut serupa dengan reaksi non enzimatis yaitu reaksi Maillard.

Aroma. Skor tertinggi aroma daging pada konsentrasi asap cair $12 \%$ dan skor terendah pada konsentrasi $0 \%$ (Tabel 4). Skor aroma daging semakin meningkat seiring dengan semakin tinggi konsentrasi asap cair. Semakin tinggi konsentrasi asap cair aroma daging semakin bau asap, hal ini disebabkan karena senyawa fenol yang terkandung dalam asap berperan terhadap pembentukan flavor pada makanan yang diasap. Senyawa fenol yang berperan dalam pembentukan flavor asap diantaranya ialah siringol, guaiakol, 4-metilguaiakol, 4 metilsiringol dan eugenol. Aroma asap tertinggi pada perlakuan asap cair $12 \%$, demikian pula halnya dengan fenol yang terkandung dalam daging.

Skor warna daging semakin menurun seiring meningkatnya lama penyimpanan. Semakin lama penyimpanan aroma daging asap semakin busuk. Bahan pangan yang mengandung banyak protein apabila mengalami kerusakan mikroba akan menghasilkan bau busuk yang spesifik protein. Bau busuk protein dikenal sebagai bau putrid dan kerusakannya disebut putrefactive spoilage. Djide (2005) juga menyatakan bahwa tahap kerusakan protein dimulai dari adanya kontaminasi mikroba pada suatu bahan. Protein dipecah menjadi molekul kecil berupa asam amino bebas, dipeptida dan gula. Dengan adanya bahan makanan bermolekul kecil tersebut akan dipergunakan oleh mikroba, maka populasi mikroba tersebut akan tumbuh dengan pesat bersamaan dengan dihasilkannya senyawa pecahan yang lebih kecil lagi, misalnya cadaverine, putreceine, asam-asam organik, $\mathrm{CO}_{2}, \mathrm{H}_{2} \mathrm{~S}$ dan $\mathrm{NH}_{3}$. Hasil uji Kruskal-Wallis menunjukkan bahwa perlakuan asap cair memberikan pengaruh yang nyata $(p<0,05)$ terhadap aroma daging.

Perlendiran. Hasil uji sensori daging pada perendaman asap cair diperoleh skor terendah yaitu 2,51 dan tertinggi 4,16. Perlendiran daging berkisar dari kategori sangat berlendir hingga kategori agak berlendir. Skor tertinggi perlendiran daging pada konsentrasi $12 \%$ dan skor terendah pada konsentrasi $0 \%$ (Tabel 4).

Skor perlendiran daging selama penyimpanan hingga 4 hari yaitu 5 sampai 1,92. Skor perlendiran daging semakin menurun seiring dengan lama penyimpanan, semakin lama penyimpanan, perlendiran daging semakin berlendir hingga rusak. Penurunan skor perlendiran daging ditandai dengan terbentuknya lendir, yang disebabkan karena protein dalam bentuk asam amino sudah mengalami proses metabolisme oleh mikroba sehingga daging menjadi basah.

Daging memiliki karbohidrat berupa glikogen dalam jumlah sedikit. Mikroba akan mengurai karbohidrat yang bermolekul besar seperti polisakarida menjadi glukosa (monosakarida) atau maltosa (disakarida). Monosakarida dalam proses glikolisis akan diubah menjadi asam piruvat. Asam piruvat ini selanjutnya diubah menjadi asam trikarboksilat dalam siklus Krebs dan akhirnya terpecah menjadi $\mathrm{CO}_{2}$ dan $\mathrm{H}_{2} \mathrm{O}, \mathrm{H}_{2} \mathrm{O}$ inilah yang menyebabkan konsistensi daging menjadi lembek (Djide, 2005). Hasil uji Kruskal-Wallis menunjukkan bahwa perlakuan asap cair memberikan pengaruh nyata $(p<0,05)$ pada perlendiran daging.

\section{Kesimpulan}

Penambahan asap cair hingga konsentrasi $12 \%$ pada daging berpengaruh terhadap sifat kimia 
daging terutama pada kadar fenol dan asam. Semakin besar konsentrasi asap cair akan meningkatkan kadar fenol dan asam, sedangkan kualitas fisik daging mengalami penurunan. Daging asap yang disimpan hingga 4 hari menunjukkan penurunan mutu seperti $\mathrm{pH}$, DIA, SM serta sensoris daging. Nilai $\mathrm{pH}$, DIA, tidak dipengaruhi oleh konsentrasi asap cair akan tetapi dipengaruhi oleh lama penyimpanan.

\section{Daftar Pustaka}

AOAC. 1995. Official Methods of Analyses. $16^{\text {th }}$ ed. Association of Official Analytical Chemists, Washington, D.C.

Chamidah, E. 2005. Evaluasi karakteristik fisik dan kimia sosis Lele Dumbo (Clarias gariepinus) selama penyimpanan 6 hari dengan penambahan dan tanpa penambahan kultur starter Lactobacillus casei. Available at www.find-pdf.com. Accession date: 19 Agustus 2010.

Darmadji, P. 1999. Potensi pencoklatan dari fraksifraksi asap cair tempurung kelapa. Laporan Penelitian. Lembaga Penelitian UGM, Yogyakarta.

Daun, H. 1979. Interaction of wood smoke component and food. Food Tech. 35: 66-70.

Djide, N. 2005. Analisis Mikrobiologi Farmasi. Laboratorium Mikrobiologi Farmasi Fakultas Matematika dan Ilmu Pengetahuan Alam, Universitas Hasanuddin, Makassar.

Fiddian, F. 2002. Optimasi produksi asap cair tempurung kelapa dengan aliran udara terkendali menggunakan response surface methodology (RSM). Skripsi. Jurusan Teknologi Hasil Pertanian. Fakultas Teknologi Pertanian, Universitas Gadjah Mada, Yogyakarta.

Fitryani. 2009. Pengaruh asap cair selama penyimpanan dingin terhadap kualitas kimia dan mikrobiologis sosis sapi. Tesis. Fakultas Peternakan, Universitas Gadjah Mada, Yogyakarta.

Gaspersz, V. 1994. Metode Perancangan Percobaan. CV Armico, Bandung.

Girard, J.P. 1992. Smoking in Technology of Meat and Meat Product. Ellis Horwood, New York.
Gronulalan, Z., A. Kose, and H. Yetim. 2003. Effects of liquid smoke on quality characteristics of Turkish standard smoked beef tongue. Meat Sci. 66: 165-170.

Guritno, A.J. 1991. Petunjuk Laboratorium Uji Sensoris dan Mutu Pangan. Pusat Antar Universitas Pangan dan Gizi. Universitas Gadjah Mada, Yogyakarta.

Lawrie, R.A. 2003. Ilmu Daging. Edisi kelima, terjemahan Aminuddin, P. UI-Press, Jakarta.

Nurwantoro. 1997. Mikrobiologi Pangan Hewan Nabati. Penerbit Kanisius, Yogyakarta.

Pszczola, D.E. 1995. Tour highlights production and users of smoke based flavors. J. Food Tec. 1: 70-74.

Ruiter. A. 1979. Color of smoke foods. J. Food Tec. 33: 54-63.

Senter, S.D., Robertson, J.A., and Meredith, F.I. 1989. Penolic compound of the mesocarp of cresthaven peaches during storage and ripening. J. Food Sci. 54: 1259-1268.

Siskos, I., A. Zotos., S. Melidou, and R. Tsikritzi. 2007. The effect of liquid smoking of fillets of trout (Salmo gairdnerii) on sensory, microbiological and chemical changes during chilled storage. Food Chem. 101: 458-464.

Soeparno. 2005. Ilmu dan Teknologi Daging. Gadjah Mada University Press, Yogyakarta.

Steel, R.G.D. dan J.H. Torrie. 1993. Prinsip dan Prosedur Statistika Suatu Pendekatan Biometrik. PT Gramedia Pustaka Utama, Jakarta.

Suradi, K. 2005. Aplikasi Model Arrhenius Untuk Pendugaan Penurunan Masa Simpan Daging Sapi Pada Penyimpanan Suhu Ruang dan Refrigerasi Berdasarkan Nilai TVB dan $\mathrm{pH}$. Fakultas Peternakan. Universitas Padjadjaran. Bandung.

Tranggono, Suhardi, B. Setiadji, P. Darmadji, Supranto, Sudarmanto, dan Armunanto. 1997. Produksi Asap Cair Dari Berbagai Jenis Kayu Dengan Proses Pirolisis. Fakultas Teknologi Pertanian. Universitas Gadjah Mada, Yogyakarta.

Yu, A. dan B. Sun. 2006. Volatile Phenolic Derivatives and its Role In Chinese Traditional Smoke-cured Meat. J. Food Tec. 4: 29-31. 